\title{
LINGUISTIC ACCOMPANIMENT OF INFORMATION WARFARE (BASED ON THE RUSSIAN-UKRAINIAN ARMED CONFLICT)
}

\author{
Olha Kyryliuk \\ PhD in Philology, Associate Professor, Senior Lecturer at the Department of Ukrainian Language, \\ Volodymyr Vynnychenko Central Ukrainian State Pedagogical University, Ukraine; \\ Postdoctoral Student at the Department of Ukrainian Philology, \\ Theory and History of Literature, Petro Mohyla Black Sea National University, Ukraine \\ e-mail: kyryluk@ukr.net,orcid.org/0000-0002-9764-8756
}

\section{Summary}

Language is an important means of waging an information war. The study of linguistic units, through which each of the parties to the armed conflict affects the recipients, makes it possible to model a fragment of the language picture of the world of society forced to live in war. Often this picture is formed under the influence of the mass media and social networks. In this paper, the associative-semantic field "enemy" in the context of the Russian-Ukrainian armed confrontation is structured on the basis of the language units used by Ukrainian information resources. Particular attention is paid to the peculiarities of the associative-semantic group (ASG) "enemy media", which include three microgroups (ASmG) with core lexemes "mass media", "journalists", "phenomena".

The constituents of ASmG "mass media" are divided into semantic rows: associations that reveal the Russian affiliation of information resources (Russia-media, Putin-TV); lexemes that indicate the propagandistic nature of the media (information Spetsnaz); lexemes to denote the harmfulness of actions (to sow confusion, to lie through one's teeth). The components of ASmG "journalists" are lexemes that indicate the privilege of individual employees of the media industry (generals of information troops) and their financial interest (millionaires from TV). ASmG "phenomena" combines terms formed from the names of famous journalists (Kyselov - kyselovshchyna, Skabeieva skabeievshchyna), as well as phraseological units that appeared as a result of the Russian media spreading false or manipulative information (crucified boy, into radioactive ash).

Keywords: armed aggression, associative-semantic field, associative-semantic modelling, constituents, associations, reflexemes.

DOI https://doi.org/10.23856/3910

\section{Introduction}

The Russian-Ukrainian armed conflict, which has been going on for seven years, is accompanied by strong information support from both sides. During this period, Ukraine and Russia have developed their own system of linguistic means to cover military operations. Linguistic tools are becoming a kind of weapon in the hands of both sides of the conflict. Successfully chosen words can significantly affect the emotional state of society, and therefore mobilize it to fight against the "enemy". Often such actions cause incitement to hatred, provoke aggression. However, a system of language signs has been built alongside this, which can evoke sympathy, pride, and support for one's own country and its defenders.

Often words become a way of identification on the principle of "own-alien". Thus, in 2014, at the beginning of the armed conflict, it was established that the unidentified gunmen who 
had captured administrative buildings in the east of the country were in fact Russians. During the capture of the building, they shouted the phrase "Za porebrik"! ("Over the curb!"). The word "porebrik" to denote "curb" is not typical for the active vocabulary of the people of Ukraine, but is a linguistic feature of the inhabitants of the Russian city of St. Petersburg (Krongauz, 2013). It was thus established that the illegal actions that led to the armed conflict in Ukraine were in fact committed by citizens of another country. As a result of this incident, the word "Zaporebrik" began to be used in public discourse as a synonym for the word "Russia", and the lexeme "zaporebriki" as a synonym for the terms "Russians" and "Russian military". This linguistic peculiarity was noted even by the Russian media: "If earlier our country was called Mordor by Russophobes, now ... it has been renamed Mordor to Zaporebrik” (tsargrad.tv, June 13, 2019).

Therefore, the comparative analysis of language units used by both sides of the conflict is now particularly relevant, because it enables to establish the language picture of the world created by the sides, with which each society has to live for many years.

The problem of reflecting war in linguistic signs has repeatedly been the subject of scientific research. The use of metaphors in the information support of hostilities was studied in particular by G. Lakoff in the article "Metaphor and War: The Metaphor System Used to Justify War in the Gulf" (1992) and M. Fabiszak in "Conceptual Metaphor Approach to War Discourse and Its Implications" (2007). Various aspects of the Russian-Ukrainian conflict are covered by D. Goriacheva (2016), Strukov \& Hudspith (2018), L. Fialkova and M. Elenevskaya (2015), A. M. Devlin (2016), L. Smoor (2017), H. Pocheptsov (2019). Linguistic peculiarities of the Ukrainian-Russian crisis are studied in the work of H. Yavorska "Language as a Component of the Conflict" (2016). The authors of the monograph "Ontology of War and Peace: Security, Strategy, Meaning” (Parakhonskyi et al., 2019) describe in detail the narratives of the Russian-Ukrainian confrontation, thoroughly explore the vocabulary of hostility in the context of information warfare.

However, the problem of structuring the set of lexemes used by the mass media to cover the armed conflict is becoming urgent. Some aspects of this topic are covered in our works (Kyryliuk, 2019; Kyryliuk, 2020).

Thus, the purpose of the proposed research is to study the structure of the associativesemantic group (ASG) "enemy media" within the associative-semantic field (ASF) "enemy" on the basis of information discourse related to the coverage of the Russian-Ukrainian armed conflict. The purpose can be realized by performing a number of tasks: to model the structure of the group under study; determine its lexical content, identify semantic and syntagmatic features of constituents.

The concepts of cognitive linguistics and psycholinguistics are the theoretical and methodological basis of the study. Particular attention is paid to the theory of associative-semantic field. The theory of cognitive models of J. Lakoff and the theory of the associative field of $\mathrm{S}$. Balli are used. The method of associative-semantic modelling is applied, with the help of which the system of lexical means is stratified, which in the language of social networks and mass media represents the conceptual sphere of "enemy media".

The Ukrainian media (names of resources are given in parentheses after each example in the text of the paper), comments on the sites of these media, as well as posts on social networks (facebook.com, twitter.com), dedicated to the Russian-Ukrainian armed conflict from 2014 to 2020 are analysed. The texts of the government portal nrada.gov.ua (National Council of Television and Radio Broadcasting of Ukraine) are also studied. Words, word-combinations, collocations, phrases that denote and characterize the media in the context of the Russian-Ukrainian armed confrontation are selected from the texts under consideration. 


\section{Associative-semantic group "enemy media"}

In our work we consider the associative-semantic field (ASF) as "a set of language / speech units to denote a certain concept, united on the basis of semantic and associative connection" (Korotych, 2007: 7). The practice of structuring associative-semantic fields is based mainly on the method of associative experiment, when the recipient reproduces associations to the word-stimulus. However, in our case, it is important to study the lexical content of media and social media texts, because these language units are imposed on society, form its perception of certain events, and accordingly determine the further reaction of recipients to certain words.

The set of language units related to the armed conflict in Donbas will vary depending on which media outlets the speakers receive information from - Ukrainian or Russian. For example, the Russian media often impose misconceptions about Ukraine on the recipient. In particular, one can observe how the term "punishers" is used to address the Ukrainian militaries, and their activities are labelled as "genocide of the Russian-speaking population" in Ukraine.

As a result (as the analysis of comments on social networks shows) for Ukrainian society, the following concepts become associations to the term-stimulus "Russian journalists": "propagandists", "liars", "Putin's mouthpieces", "help kill Ukrainians", and therefore this gives grounds to consider the concept of "Russian journalists" within the ASF "enemy". The entrenchment of these associations in the mind of the recipient is largely imposed by the texts of the media and social networks.

In terms of war, both sides of the conflict are forced to use hate speech to demonize and depersonalize the enemy in order to obtain public consent to hostilities. Therefore, it is expedient to study the structure of the ASF "enemy" in the context of the armed Russian-Ukrainian conflict. Earlier in our works, 5 associative-semantic groups within the ASF "enemy" have been identified: "enemy troops", "enemy country", "enemy society", "enemy phenomena", "enemy media" (Kyryliuk, 2020).

In this paper, we will focus in detail on the studied structures of ASG "enemy media". It is formed by constituents to denote Russian journalists, Russian information resources, and related concepts that are relevant in the context of coverage of the armed conflict. Depending on this, within the study group, three microgroups (ASmG) are identified: "media", "journalists", "phenomena". The lexical content of each of the microgroups is formed into separate associative-semantic rows (ASR).

\subsection{Associative-semantic microgroup (ASmG) "media"}

This microgroup is represented by the rows of words, which in the media and network discourse convey the general attitude to the Russian or pro-Russian media. There are five associative-semantic rows within the group.

ASR $_{1}$ combines lexemes with a component that indicates the Russian or pro-Russian direction of the media. These are mainly components of "Russia", "Kremlin", "Putin" and derivatives (Russia-TV, Russia-media, Rashist media, Kremlin or pro-Kremlin media, Kremlin-TV, Putin's media, Putin-TV, Putin's mouthpiece, media with pro-Russian rhetoric, Moscow media). For example: At home, the Kremlin media convince its audience that the world outside of Russia is dangerous (nrada.gov.ua, January13, 2020).

Such lexemes label not only the media with direct registration in Russia, but also resources that are registered in Ukraine, but cover Kremlin policy.

$\mathbf{A S R}_{2}$ is formed by words that indicate the propagandistic nature of the Russian media: propagandists, ideological units of the Kremlin, information weapon, weapon of information terror, Russia's hate machine, information troops, information units of Russian Federation, 
the giants of Putin's agitprop (agitation and propaganda). In the Ukrainian information space, "Russian media" and the concept of "journalism" in general have become synonymous with "propaganda". They are accused of assisting the Russian government to implement military policy. Hence the use of a large amount of military vocabulary addressed to these media, which associatively equates the work of the media to the work of law enforcement agencies and the army: information saboteurs, subversive Spetsnaz (Special Forces), information Spetsnaz of Putin's regime, hotbeds of Russian disinformation, recruiters. For example: "Russia does not employ journalists, but information subversive Spetsnaz. These are information troops, they carry out information aggression" (ukrinform.ua, November 27, 2014).

$\mathbf{A C R}_{3}$ represents lexemes and word combinations that contain the onym "Goebbels", which also indicates the propagandistic nature of the Russian media, but also associates them with the crimes of Nazi propaganda: Goebbels-TV, Goebbels troops of the Kremlin, Goebbels' servants, Goebbels' students, Goebbels'fledglings, Goebbels-TV inform empire. For example: "Who, and for what "merits" is invited to the Russian "Goebbels-TV"? (lb.ua, March10, 2017).

The motivator for the creation and use of such lexemes and word combinations is the name of Josef Goebbels, the Reich Minister of Public Enlightenment and Propaganda of Germany who provided a powerful Nazi propaganda from 1933 to 1945 . Ukrainian media systematically compare the principles of Russian information resources with the principles of Goebbels propaganda. For example: "Russian TV is built exactly according to Goebbels' wills" (nv. ua, September 14, 2014).

Devotion to Goebbels' principles was also mentioned by Russian President V. Putin: "After all, Goebbels said: the more improbable a lie, the faster it will be believed. And he achieved his goal, he was a talented man" (V.Putin, July 9, 2014).

The use of the onym Goebbels in the labelling of the Russian media, signals the perception of these resources as hostile, which automatically includes such words in the associative-semantic field "enemy".

$\mathbf{A S R}_{4}$ combines lexemes that have a negative expressive and emotional connotation, and therefore facilitate to express a negative evaluative attitude of the recipient: garbage, Putin's garbage, Kremlin garbage, garbage media, garbage cans, drain tanks. For example: "In Ukraine, Russian disinformation works in several "columns". The first is the pro-Russian media, which allegedly adhere to journalistic standards. The other "column" - "garbage cans" (detector.media, October 7, 2019).

ASR $_{5}$ combines word combinations to denote "actions" performed by Russian and pro-Russian media. The core semantic components in such combinations are the lexemes "chaos", "lie", "aggression", "hatred", "manipulation", "murder": sow chaos, lie, incite hatred, lie through one's teeth, destroy the foundations of the civilized world, spread propaganda, wage a propaganda war, manipulate, distort reality, serve Putin, conduct "vata" (cotton wool) policy, destroy the mind, kill the brain. For example: "The main goal of Russian propaganda is to sow chaos in the minds of the people of the Western world" (espreso.tv, June 27, 2017).

\subsection{Associative-semantic microgroup "journalists"}

The expediency of distinguishing such a group is dictated by the presence of some particularly well-known journalists who have become the embodiment of the anti-Ukrainian principles of the Russian media. Such journalists, who were especially notable for inciting hostility towards Ukraine, include D.Kyselov, O.Skabeieva, V.Soloviov. The scale of the influence on the recipients and the emotional reaction of the society to the activities of these people are so great that the terms "kyselovshchyna", "skabeievshchyna", "soloviovshchyna", appeared and became synonymous with the words "propaganda", "lie". 
$\mathbf{A S R}_{1}$. As for these journalists, the media often use the terms that are described above (in paragraph 3.1, $\mathrm{ASR}_{2}, \mathrm{ASR}_{3}$ ), such as: propagandist, propaganda repeater, Kremlin mouthpiece, soldier of information warfare. For example: "Goebbels' fledgling - Dmytro Kyselov (radiosvoboda.org, May 4, 2015). That is, it makes possible to consider the phenomenon of intersection of groups within the associative-semantic field.

The word combination "drain tank" deserves special attention as a semantic innovation. Traditionally, this phrase was used to denote information resources of dubious quality, and was mentioned above ( $\mathrm{ASR}_{4}$ p.2.1). However, on January 24, 2019, Russian journalist O.Skabeieva tried to prevent the Ukrainian TV channel from broadcasting live from the Parliamentary Assembly of the Council of Europe. The Ukrainian journalist replied: “... you annexed Crimea, ... we will not allow our live broadcast to be annexed. We know how loudly your drain tank works, which is called mouth for normal people" (TV Channel "Priamyi", January 24, 2019).

After this phrase, the nickname "Drain Tank" became attached to O. Skabeeva in the information space of Ukraine. For example: “... one of the harshest Kremlin propagandists O.Skabeieva is well known to society as the "drain tank" of the Kremlin" (ua-stena.info, December 24, 2019).

$\mathbf{A S R}_{2}$ unites connotative onyms - the names of famous journalists (Kyselov, Skabeieva, Soloviov). These proper names are used to mean "journalist, who tells a lie, manipulates the facts" (to become Kyselov, Skabeieva in the Ukrainian style). There are cases of using these onyms in the plural in order to form a generalized concept of Russian journalists: "There are such virtual "curtains" through which many, many Skabeievas pass in different jackets"... (gordonua.com, January 14, 2020). In the Ukrainian information space, the Ukrainian journalist N. Moseichuk began to be called "Skabeieva" (Ukrainian Skabeieva, Skabeeva No.2, the second Skabeieva). For example, the title of the article "Skabeeva No.2: Yanina Sokolova admitted that she was very sorry for Moseichuk" (replyua.net, August 14, 2019).

In social networks, as well as in the comments of readers on information sites, the lexeme "skabeieva" is written in lower case, which confirms the appellativation of this onym: "Moseichuk turned into skabeeva" (comment on censor.net.ua, May 18, 2019).

$\mathbf{A S R}_{3}$ is united by words that indicate the privilege of individual journalists: Putin's generals of information, generals of information troops, generals of propaganda, Putin's people, ministers of propaganda, and elite of television army. For example: "Putin's generals of information": the media told how Russian television works" (unian.ua, October 4, 2017).

$\mathbf{A S R}_{4}$ forms word combinations that indicate the financial interest of journalists: people who sell themselves, millionaires from TV, they are paid for humiliation, on Putin's salary, earn money on the deaths of Ukrainians, traitors. For example: "These are people who sell themselves" (nv.ua, July 29, 2020), "Millionaires from TV' (nv.ua, February 17, 2019).

ASR $_{5}$ combines evaluative adjectives: odious, infamous, notorious, scandalous. For example: "Another odious showman - Dmytro Kyselov" (nv.ua, 02/17/2019).

$\mathbf{A S R}_{6}$ is formed by constituents that indicate the assessment of the actions of journalists. In this case, it is worth pointing to the intersection at the boundary of the ASmG. The lexemes used here are also characteristic of a generalized explanation of the activities of the Russian media (discussed above in $\mathrm{ASR}_{5}$ within the ASmG "media"): lie, manipulate, sing odes to Putin, deserve The Hague, must be judged. For example: "Dmytro Kyselov - ... resorts to outright lies, manipulations, and incitement to hatred towards Ukrainians" (nv.ua, February 6, 2019).

\subsection{Associative-semantic microgroup "phenomena"}

Getting Ukraine in the top of Russian news contributed to the emergence of certain new concepts and phenomena that have become fixed in the information space and have become part of the active vocabulary of speakers. There are two rows within the group. 
ASR $_{1}$ combines lexemes formed from the names of famous propagandists: "hebbelsivshchyna", "kyselovshchyna", "skabeievshchyna", "propaHordonshchyna". The lexeme "hebbelsivshchyna" is dominant in this row, which is used to denote propaganda techniques that manipulate public opinion, spread lies, incite national, religious and any other kind of social hatred. The terms "kyselovshchyna", "skabeievshchyna", "soloviovshchyna" are formed on the same principle from the surnames of the already mentioned Russian journalists (D.Kyselov, O.Skabeieva, V.Soloviov). For example: "Another insanity of "kyselovshchyna" appeared on the Internet" (tsn.ua, December 10, 2014). These terms have the same semantics as the lexeme "hebbelsivshchyna", but they have another meaning - "anti-Ukrainian propaganda", and the phrase "carry kyselovshchyna" is used to mean "spread false information of anti-Ukrainian content". For example: "The network reacted sharply to the publication, accusing the publicist of "kyselovshchyna" (nnovosti.info, July 15, 2017).

The term "kyselovshchyna" has become so common that it began to be called anti-Ukrainian information published not only by Russian information resources, but also in the media of other countries: "American kyselovshchyna. The Western Front of Ukrainophobia" (siver.com. ua, May 10, 2016).

This group includes the term "propaHordonshchyna", formed from the name of Ukrainian journalist D.Hordon, who was repeatedly accused in the media of supporting the Russian agenda, especially after an interview with Russian terrorist I.Hirkin. For example: "Skabeievshchyna" and "propaHordonshchyna" in the Ukrainian information space (enigma.ua, April 6, 2020). The term "soloviov-kyselov-propaGordonshchyna" is even used.

$\mathbf{A S R}_{2}$ combines a number of phraseological units, motivated by particularly resonant events, facts, fakes, threats, published in the Russian media: into radioactive ash, crucified boy, to drink the blood of Russian babies, to eat Russian-speaking children, "how are the khokhols"(the word khokhol is used as an ethnic slur for Ukrainians), a picture for the Russian mass media, Yarosh's business card, to take off to the National guard (Russian fake that in Ukraine all men are taken off the train and sent to the front), two slaves (Russian fake that Ukrainian militaries are promised to get for the war "two slaves"), krymnash (Crimea is ours), vyvsibreshete, vyvsovrotie (you all lie).

Let us consider the extra- and intralingual peculiarities of some phraseological units.

"Crucified boy" is a phraseological combination that has become a symbol of the absurdity of Russian propaganda. In 2014, Russia's TV Channel One spread false information that the boy had been crucified by the Ukrainian military. The word combination "crucified boy" has become fixed in the information space with the meaning "absurd, untrue information". For example: "Every time a conditional "crucified boy" is invented, there is nothing new for Russian propaganda" (segodnya.ua, December 1, 2019).

"Into radioactive ash" - a phrase that became popular after Russian journalist D. Kiselyov had threatened the United States with nuclear weapons on the day of the so-called "referendum" in Crimea: "Russia is the only country that capable of turning the United States into radioactive ash (TV Channel Russia 1 ", March 16, 2014). The phrase "radioactive ash" quickly became a meme and began to be used with several meanings: 1) unfounded threats to a stronger opponent, 2) Kremlin propaganda, 3) journalist D. Kyselov, 4) physical destruction, 5) ironic, humorous threat. For example: "Radioactive ash" penetrated the brains of Russians (kontrakty. ua, November 7, 2014).

"Drink the blood of Russian babies", "eat Russian-speaking children" - phraseological combinations, which in the Ukrainian information space demonstrate the absurdity of accusations of Russian propaganda that the Ukrainian military allegedly harms Russian-speaking 
children. For example: "17 small residents of Starobilsk district proved that Ukrainian soldiers "do not eat Russian-speaking children" and are ready to protect them" (armyinform.com.ua, December 26, 2019).

"How are the khokhols" is a phraseological combination that denotes the desire of the Russian media to focus on events in Ukraine, without noticing the problematic topics in their own country. For example, the title of the article "How are the khokhols: Social networks troll Russians for indifference to the situation in Russia" (tsn.ua, April 2004, 2015).

"Picture for the Russian media (Russian TV)" is a phrase with the meaning "provocative measures taken to show Ukraine in a negative light". This phrase gained popularity with the beginning of hostilities in Donbass, when journalists noticed a tendency for Russian media to appear at the sites of serious shelling either before or immediately after the shelling: "Residents point out that on the eve of all provocations with shelling of residential areas Russian journalists promptly appear in the activity zone and create a picture for the Russian TV' (ukrinform. ua, June 19, 2014). The Ukrainian authorities often resort to this phraseological unit, adverting to participants of any possible provocative protests: "Zelenskyi called on participants of action on October 14 "not to create a picture for Russian media" (zaxid.net, October 13, 2019).

"You all lie" (Ukr. vyvsibreshete, Russ. vy'fsyovryoti) - the phrase first appeared in the Russian segment of the Internet and indicated the reaction of Russian hooray-patriots to the true historical or political facts. Since the beginning of the armed aggression in 2014, Ukrainians have been using this phrase to ironically denote the reaction of Russian citizens to the truthful news about Ukraine: "Well, of course, we remember. And there were no parades, \#Vy'fsyovryoti" (account "White Bear", twitter.com, November 21, 2015). However, over time, this phrase began to be used to denote a person's reaction to any facts that reveal ordinary issues from another angle. Sometimes this phraseological unit is used literally as an appeal to the Russians (Kyselovshchyna, vyfsibreshete! (Ua.korrespondent.net, December 10, 2014). If Russians trampled the dollars as they trample the American flag, it would be sincere. And so \# vy'fsyovryoti”' (Patriotoff account, twitter.com, March 19, 2015).

\section{Conclusions}

Thus, as a result of the study, it became possible to structure the ASF "enemy" in the context of the Russian-Ukrainian armed conflict, in particular to study in detail the content of the ASG "enemy media". The constituents of this group are lexemes used in the media and social networks to refer to Russian journalists, Russian information resources, and related concepts. Three microgroups within the group are: "media", "journalists", "phenomena".

The constituents of ASmG "media" are divided into 5 rows. The first is formed by associations that indicate the Russian affiliation of information resources (Russia-media, Putin-TV), the second is grouped on the basis of lexemes that emphasize the propagandistic nature of the media (weapon of information terror, information troops, information Spetsnaz). The presence of the onymic component "Goebbels" in the structure of lexeme also indicates propagandistic activity; constituents with this component are united in the third ASR (Goebbels-TV, Goebbels' fledglings). The fourth ASR combines lexemes that express a negative expressive-emotional-evaluative connotation (garbage, litter, drain tanks). The fifth row groups lexemes to denote the activities of the media (lie through one's teeth, distort reality).

The components of ASmG "journalists" are lexemes that indicate the privilege of individual media workers (generals of information troops, generals of propaganda); their financial interest (millionaires from TV, traitors); evaluative signs (odious, infamous, scandalous). 
ASmG "phenomena" unites constituents within two ASR: 1) terms formed from the names of famous journalists (kyselovshchyna, skabeievshchyna); 2) phraseological units that arose as a result of the spread of false or manipulative information by the Russian media (crucified boy, into radioactive ash).

The phenomenon of intersection of individual rows and groups within the ASF is also observed. In particular, lexemes and metaphorical combinations are often used in information discourse both to refer to individual journalists and to generalize the Russian media (propagandists, Putin's mouthpieces).

Our next explorations will be devoted to further in-depth study of the ASF "enemy" in the context of the Russian-Ukrainian armed conflict.

\section{References}

Devlin, Anne Marie. (2017). Lard-eaters, gay-ropeans, sheeple and prepositions: lexical and syntactic devices employed to position the other in Russian online political forums. Russian Journal of Communication, 9(1), 53-70. doi: 10.1080/19409419.2016.1219642

Fabiszak, M. A. (2007). Conceptual Metaphor approach to war discourse and its implications. Poznań: Wydawnictwo Naukowe UAM.

Fialkova, L., Yelenevskaya, M. (2015). The crisis in Ukraine and the split of identity in the Russian-speaking world. Folklorica, Vol. XIX. doi: 10.17161/folklorica.v19i1.5721

Goriacheva, D. (2016). Understanding the "Ukrainian crisis." Metaphors used by Ukrainian, German, and British leaders in 2014-16. Ideology and Politics, 1(6), 86-152. [in Ukrainian] Korotych, K. V. (2007). Asotsiatyvno-semantychne pole "bezpeka / nebezpeka" v dyskursi ukrainskoi presy XX-XXI stolit [Associative-semantic field "safety / danger» in Ukrainian press discourse of XX-XXI centuries] Avtoref. dys. kand. filol. nauk [PhD's thesis abstract]. Kharkivskyi natsionalnyi universytet imeni V.N. Karazina, Kharkiv. [in Ukrainian]

Krongauz, M. (2013). Russkij na grani sry'va (interv'yu s direktorom Instituta lingvistiki RGGU M.Krongauzom) [Russian on the verge of collapse (interview with M. Krongauz, director of the Institute of Linguistics of the Russian State University for the Humanities)]. Rossijskaya Gazeta, 19 (5995). https://rg.ru/2013/01/31/yazyk.html [in Russian]

Kyryliuk, O.L. (2019). Asotsiatyvno-semantychne pole «viina»v suspilno-politychnomu dyskursi [Associative-semantic field "war" in socio-political discourse]. Svit Movy - Svit u Movi: Proceedings of the V-th International conference, Kyiv, 74-77. [in Ukrainian]

Kyryliuk, O.L. (2020). Struktura asotsiatyvno-semantychnoho polia "voroh" v dyskursi informatsiinoi viiny [Structure of the associative-semantic field "enemy" in the discourse of the information war]. Aktualni Pytannia Humanitarnykh Nauk, 29(2), 53-58. [in Ukrainian]

Lakoff, G. (1992). Metaphor and war: The metaphor system used to justify war in the gulf. Journal of Cognitive Semiotics, IV(2), 5-19.

Parakhonskyi, B., Yavorska, H. (2019). Ontolohiia viiny i myru: bezpeka, stratehiia, smysl [Ontology of war and peace: security, strategy, meaning]. Kyiv: NISD. [in Ukrainian]

Pochepczov, G. (2019). Kognitivny'e vojny'v soczmedia, massovoj kul'ture i massovy’x kommunikaciyax [Cognitive wars in social media, mass culture and mass communications.]. Kharkov: Folio. [in Russian]

Smoor, L. (2017). Understanding the narratives explaining the Ukrainian crisis: identity divisions and complex diversity in Ukraine. Acta Universitatis Sapientiae, European and Regional Studies, 11(1), 63-96. https://doi.org/10.1515/auseur-2017-0004

Strukov, V., Hudspith, S. (2018). Russian culture in the age of globalization. New York: Routledge. Yavorska, H. (2016). Mova yak skladnyk konfliktu [Language as a component of conflict]. Media Studies: Mezhdisciplinarny'e Issledovaniya Media, 103-108. [in Ukrainian] 